\title{
Land use Land Cover Change Detection and Measuring Horticulture Expansion through Remote Sensing and GIS Techniques in Rambiara Catchment, Kashmir Valley, India
}

\author{
Mohammad Taufique ${ }^{1}$ and Vajahat Khursheed ${ }^{2^{*}}$ iD \\ ${ }^{1}$ Department of Geography, Aligarh Muslim University, Aligarh, Uttar Pradesh-202001, India \\ ${ }^{2}$ Aligarh Muslim University, Aligarh, Uttar Pradesh-202001, India \\ *vajahatkhursheed@gmail.com (Corresponding Author)
}

ARTICLE INFORMATION

Received: December 17, 2020

Revised: January 15, 2021

Accepted: January 20, 2021

Published Online: March 26, 2021

Keywords:

LULC, GIS, Horticulture, Rambiara,

Catchment

DOI: $10.15415 /$ cs.2021.82004

\section{ABSTRACT}

Horticulture industry is backbone of the economy of the Jammu and Kashmir, it has increased spontaneously from a recent couple of decades and had immensely impacted the socio-economic conditions of the inhabitants of the Rambiara Catchment. The study aimed to identify the varied land use and land cover categories prevailing over the Rambiara catchment and attempted to study the temporal changes. Multispectral images of the Landsat 7 and Landsat 8 were brought into use by making the LULC classes through the maximum supervised classification for the images of year 1999 and year 2019. Whole of the study area was classified into eight major land cover categories i.e., Horticulture, Settlement, Water, Riverbed, Dense Forests, Sparce Forests and Waste Lands. The results obtained depicted that there was a large-scale positive change observed by the land cover categories of Horticulture +172.67 percent, Settlement +112.06 percent and sparse forest by +28.44 percent. The horticulture remained the highest achiever over the last 20 years and this is because of the high cash value realized from fruits, less agricultural production obtained from crops other than fruits and also due to changing climate.

\section{Introduction}

Horticulture is the science and art of the development, sustainable production, marketing, and use of high-value fruits, intensively cultivated food and ornamental plants. Horticultural crops are diverse; they include annual and perennial species, delicious fruits and vegetables, and decorative indoor and landscape plants (Michigan State University, 2020). The horticulture industry is responsible for managing several environmental issues pertaining to the fertility of the soil, the salinity of soil caused by the over-application of irrigation, conservation of the local vegetation, and the usage of the water resources. Further, it enriches its quality (Horticulture Innovation Australia, 2020). Horticulture crops constitute a considerable proportion of Global agricultural output; additionally, these fruit products are possessive of high export value besides providing an attractive yield per unit of land (Ravichandra, 2014; McKeown et al., 2005). Horticulture encompasses a brilliant potential of expansion through diversification capacity, which can augment the agriculturists' daily income. Besides providing livelihood and ecological balance; Horticulture is the essential component of the food and nutritional security for millions of people throughout the Globe. (Nath \& Gaddagimath, 2011; Singh \& Malhotra, 2011).

India mainly focused on the sector of horticulture in the decade of 1990's which led to the alternative growth in India's agriculture (Bhat, 2017). India is one of the diverse countries with a considerable land bank mainly confined for horticulture; this enough cultivable land availability is capable of producing bumper horticulture produce. A vital proportion of Indian agricultural produce constitutes horticultural crops and these crops comprise about 37 percent of the total agricultural exports from India (NCERT, 2018). From few years, India witnessed an increment in the production of fruits where significant progress was recorded through the expansion in the area resulting in the large display. During 2017-18, the production of horticulture crops was 311.71 Million Tonnes from 25.43 Million Hectares. The vegetable production has increased from 101.2 Million Tonnes to 184.40 Million Tonnes since 2004-05 to 2017-18 and production of 
fruits has risen from 50.9 Million Tonnes to 97.35 Million Tonnes since 2004-05 to 2017. The progress has tremendously helped curb unemployment and led to nutritional security (Government of India, 2018).

Horticulture undoubtedly has flourished as a vibrant sub-sector of agriculture and incorporates a brilliant potential to expand its footprints in Jammu and Kashmir (Khursheed \& Taufique, 2020). Horticulture is on the way to grow more swiftly in the upcoming years, despite hindrances caused to it by facing simultaneous lockdowns. This justifies that it has an effective mechanism to cater to and support the growing population in a very handsome. At this juncture, when all the sectors are in shambles, the fruit industry remains a beacon of hope for much unemployed youth and local families in Jammu and Kashmir (Dar, 2020). Jammu and Kashmir are endowed with immense natural resources, including water, mountains, beautiful and fertile Kreriwa lands. Those soils have become a hub for the growth and development of horticultural activities. Kashmir valley enjoys a monopoly in the production of world-class saffron, and even in the case of dry fruits like walnuts, Almonds, there is no parallel to Jammu and Kashmir. A large chunk of the apple in India is produced in Kashmir. Horticulture is one of the dominant sectors considered as the backbone of the economy of Jammu and Kashmir as it has an annual turnover of more than 1200 crores. It has also generated employment through its direct and allied activities (Darzi, 2016). The area under study lies in the southern part of the Kashmir valley, where there are widespread horticulture fruits. In the Rambiara catchment, most people are dependent on horticulture, which even provides employment, livelihood, and hope for lakhs of inhabitants'. This area is well suited for the temperate horticulture crops and produces a bumper production, hence keeping the importance of this sector in mind, it becomes imperative to study and measure the area under the horticulture through the modern techniques Land use/land cover (LULC) changes are highly intermingled and responsible for widespread agricultural patterns on earth's surface. The remotely sensed data acquired from the satellites proved to be quite authentic and encouraging for assessing and mapping the varied land use and land cover patterns coupled with the accurate temporal variations. Such changes are quantifiyable and possible through the techniques of GIS even if the resultant spatial datasets are of different scales/ resolutions (Andualem, Belay $\&$
Guadie, 2018; Sarma et al., 2001; Butt et al., 2015). In mapping natural resources, remote sensing accompanied by Geographic Information system has significantly contributed to detecting land cover changes (Hassan et al., 2016). The same technology has been quite often used to measure the areas changes under horticulture in several parts of the world. From the recent couple of decades, crop modeling in horticulture has become an important tool for this industry's overall wellbeing (Gary, Jones \& Tchamitchian, 1998). The applicability and importance of these techniques can be realized from the fact that even the Forecasting Agricultural output using Space, Agrometeorology and Land-based observations (FASAL) program has been launched by the Govt of India which focusses on estimating the preharvest production of several crops at several levels. Remote sensing has several times proved its applicability as a standard tool to quantify the area under the different horticulture crops.

Therefore, the ongoing study is aimed to address the two broad objectives both are related to the dynamic shift of land use land cover changes along the length and breadth of the Rambiara Catchment. The Primary attempt is to revive and measure the Land use land cover changes by using geospatial technology. In contrast, the study's secondary aim is to find out the growth of horticulture extension in the study region over a temporal basis.

\section{Study Area}

Rambiara river is a tributary of the Jhelum river, and it originates from Rupri ridge in the Pir Panjal range of south Kashmir Himalayas. The Rambiara Catchment comprises an area of about $670 \mathrm{Km}^{2}$. Rambiara catchment is stretched across the Shopian and Pulwama districts, where most of its hilly area is part of the Shopian district, and a plain stretch of this catchment lies in the Pulwama. On the upper reaches, Rambiara catchment is dominated by dense and sparse forests of the famous tree species of Pinus wallichiana, Cedrus deodara, Abies pindrow, and Piceasmithiana; also, some types of shrubs and herbs of medicinal value are found in the forests (Masood \& Pandit, 2014). In the plain areas of the study area, horticulture is a profound agricultural and economic activity. Some best variety and quality fruits like cherry, walnuts, almonds, and apples are produced on this earth segment. 


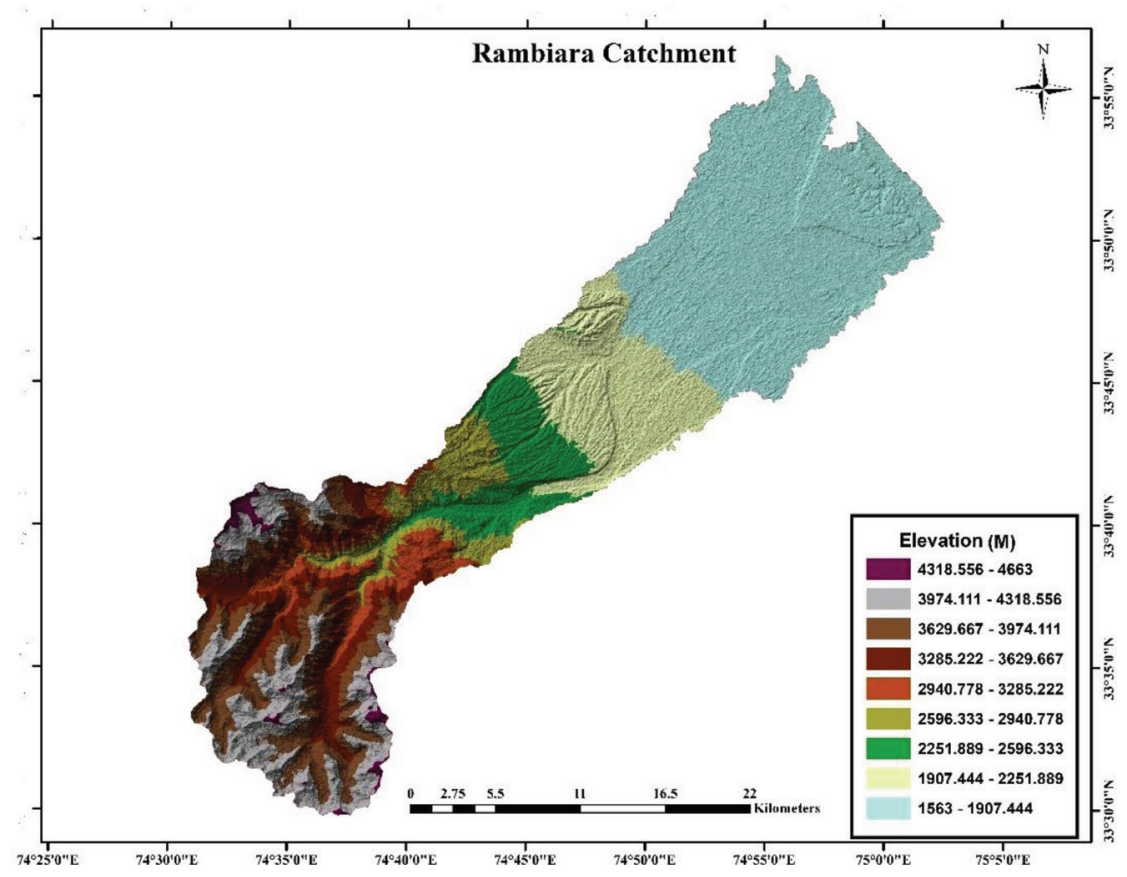

Figure 1: Map of the Rambiara Catchment (Source: Prepared by Researcher with the help of Geospatial Data).

\section{Datasets and Methodology}

The study is based on the secondary sources of data where GIS techniques were employed on the different satellite images. The data used was in the form of the images acquired from the United States Geological Survey (USGS, n.d.) pertaining to the two different time periods. Images of Landsat 7 ETM 1999 for the month of June and same month image of Landsat 8 OLI for 2019 was downloaded for the visual interpretation and identification of land use land cover classification.

The base maps were prepared, and the study area was delineated with the help of the Arc Hydro Tools supplemented with the ArcGIS Suit 10.3. For the detection of dynamics of Land Use and Land Cover, ERDAS Imagine 14 software was brought into consideration. Maximum likelihood classification was used to prepare the land use land cover of the images of 1999 and 2019. Spectral signatures of each category with a common size of 100 were selected and later were grouped to produce eight LULC classes.

\section{Results and Discussion}

\section{LULC Rambiara Catchment}

Land cover documentation presents a picture of how its surface is covered with the varied forms of forests, agriculture, built up and other land and water types. Land use on the other hand, shows how the interaction of the human factor takes pace with this naturally existing land cover surface; these land-use changes may be both developmental as well as conservational in nature (NOAA, 2020). These Land Use Land Cover (LULC) are in a big way providing information for the understanding of the landscape for the users. These landcover maps can be used to get information related to the agricultural ecosystems, forest conversions, surface water bodies on a temporal basis (NRSC, 2020). The study area was considered for the detection of dynamics in LULC because of the several reasons for the critical land-use changes in this area in the agriculture and forest land covers. The study was conducted pertaining to the time period of 20 years from 1999 to the year 2019. The interpretation of the remotely sensed data revealed that there had been a tremendous change observed in some land cover categories like forests, agriculture, horticulture.Table 1 demonstrates the exact position of all the LULC types where it was found that settlement and horticulture land achieved a manifold increase in the area under them as they both expanded with a growth rate of above 100 percent. In the Settlement or built-up category, there was a growth rate of 112.06 percent in the reference period; the area increases from $10.12 \mathrm{Km}^{2}$ in 1999 to $21.46 \mathrm{Km}^{2}$ in 2019, while horticulture also 
increased leaps and bounds from $64.18 \mathrm{Km}^{2}$ to $175 \mathrm{Km}^{2}$. An overwhelming change in the human population has largely impacted these two land cover classes. Another category of Sparce vegetation type showed positive growth of 28.44 percent, and in absolute terms, area rouse by about $56 \mathrm{Km}^{2}$ in the category of sparce forests. The LULC category of waste lands accounts to be positive with the growth rate of 13.89 percent with an extension of about $8.94 \mathrm{Km}^{2}$. Rest all the other class got decreased their area because of several reasons. Dense forest land cover class has produced a very alarming situation, and those forests are incredibly significant from the climatic and environmental point of view. But current study revealed that there is a profound negative impact relating to those forests. The interpretation of the temporal data verified that the contraction of the forest lands has been devastating. The area under the dense forest has reduced by $50 \mathrm{Km}^{2}$ from $124.57 \mathrm{Km}^{2}$ in 1999 to as low as 74.49 $\mathrm{Km}^{2}$ in 2019, the percentage negative decrease accounts to be -40.20 percent in the discussed time period. This reduction is caused by the reckless cutting of trees to construct houses and for fuel purposes. Another demining Land use category arrives to be the agriculture as large tracts of the agriculture land has been converted to horticulture and for the construction of houses. This reduction has reached a point that presently, only $73.77 \mathrm{Km}^{2}$ area is under agriculture. The water category has also faced the brunt of this changing scenario as there has been a negative change of -16.46 percent in this class over a span of 20 years. However, due to varied reasons, the landscape of the Rambiara catchment is changing.

Table 1: Area under different Land use Land Cover Classes.

\begin{tabular}{|l|l|l|l|l|}
\hline \multirow{2}{*}{ Class } & \multicolumn{2}{|c|}{ Year } & \multicolumn{2}{c|}{ Change } \\
\cline { 2 - 5 } & $\mathbf{1 9 9 9}$ & $\mathbf{2 0 1 9}$ & $\mathbf{K m}^{\mathbf{2}}$ & $\mathbf{( \% )}$ \\
\hline Settlement & 10.12 & 21.46 & 11.34 & 112.06 \\
\hline Water & 4.92 & 4.11 & -0.81 & -16.46 \\
\hline River Bed & 13.52 & 11.82 & -1.7 & -12.57 \\
\hline Horticulture & 64.18 & 175 & 110.82 & 172.67 \\
\hline Dense & 124.57 & 74.49 & -50.08 & -40.20 \\
\hline Sparse & 199.03 & 255.63 & 56.6 & 28.44 \\
\hline Agriculture & 208.87 & 73.77 & -135.1 & -64.68 \\
\hline Waste & 64.37 & 73.31 & 8.94 & 13.89 \\
\hline
\end{tabular}

Source: Compiled from the images of Landsat 7 and Landsat 8 images by the researcher.

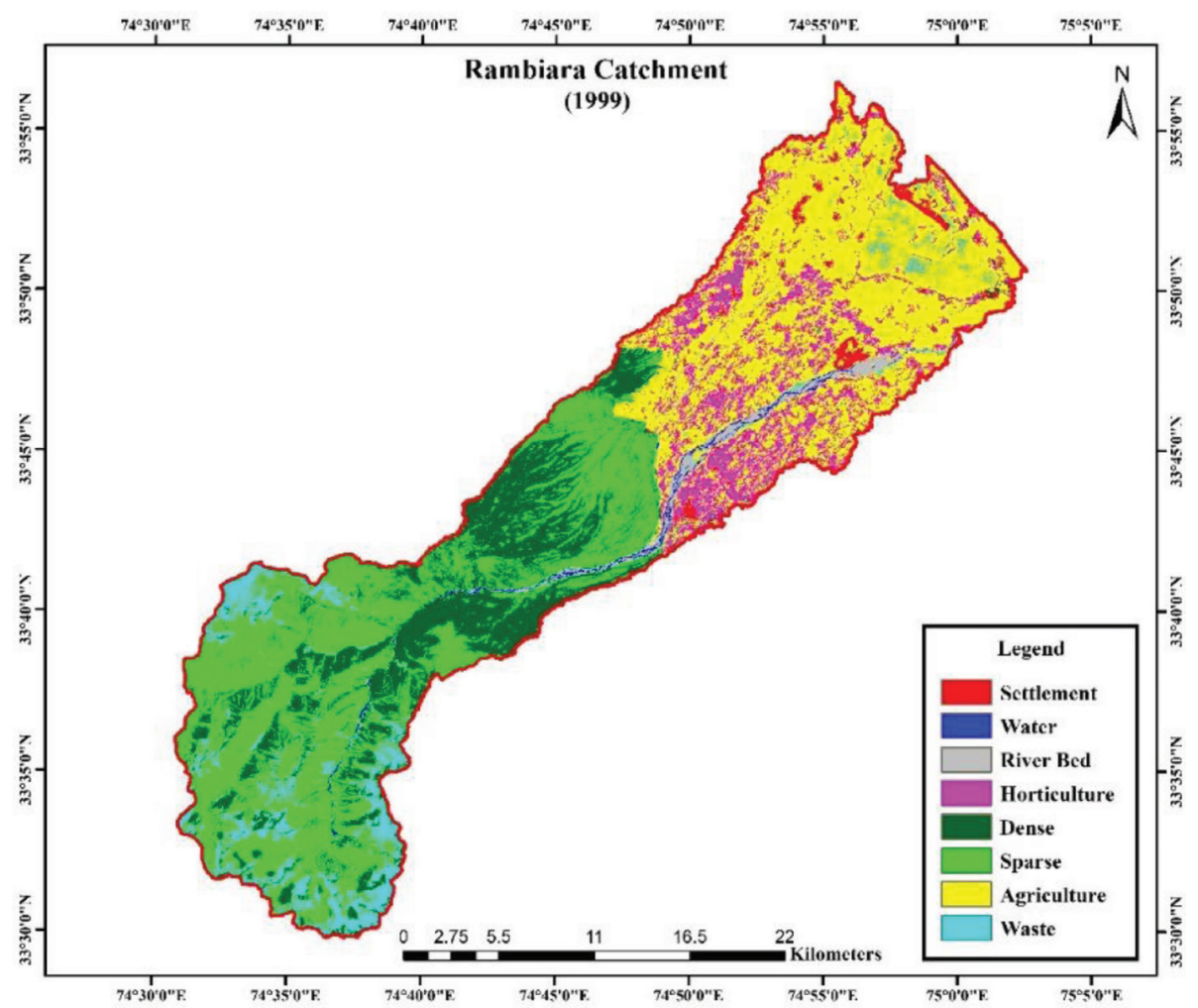

Figure 2: LULC, 1999 (Source: Prepared from the image of Landsat 7 image by the researcher). 


\section{Growth of Area under Horticulture}

The current age has developed methods like SiteSpecific Crop Management, which turned out to be very helpful in the horticultural crops like fruit and nuts to increase the productivity and optimize utilization of resources. This technology further enhances horticulture farming by delineating the orchids, which are quite useful in the decision-making process about the timing and quantity of irrigation, pesticides, and fertilizers (Deb, Singh \& Kumar, 2018). Recent developments in the improvised resolutions of satellite sensors the horticulture remote sensing have been directed towards new heights (Marinelli, Scavuzzo, Giobellina \& Scavuzzo, 2019). Further (Rao, Ravishankar, Raj \& Nagajothi, 2004), in their study, attempted to estimate the date of harvest of some fruit crops along with their production estimation. A simple assessment with the help of remote sensing has been made in the Study region. Kashmir valley is endowed with numerous assets, and horticulture being one among them, is expanding leaps and bounds across the length and breadth of this region of the earth. Rambiara catchment comprising of the parts of two southern valley districts of Shopian and Pulwama are among the leading fruit-producing pockets of Kashmir valley.

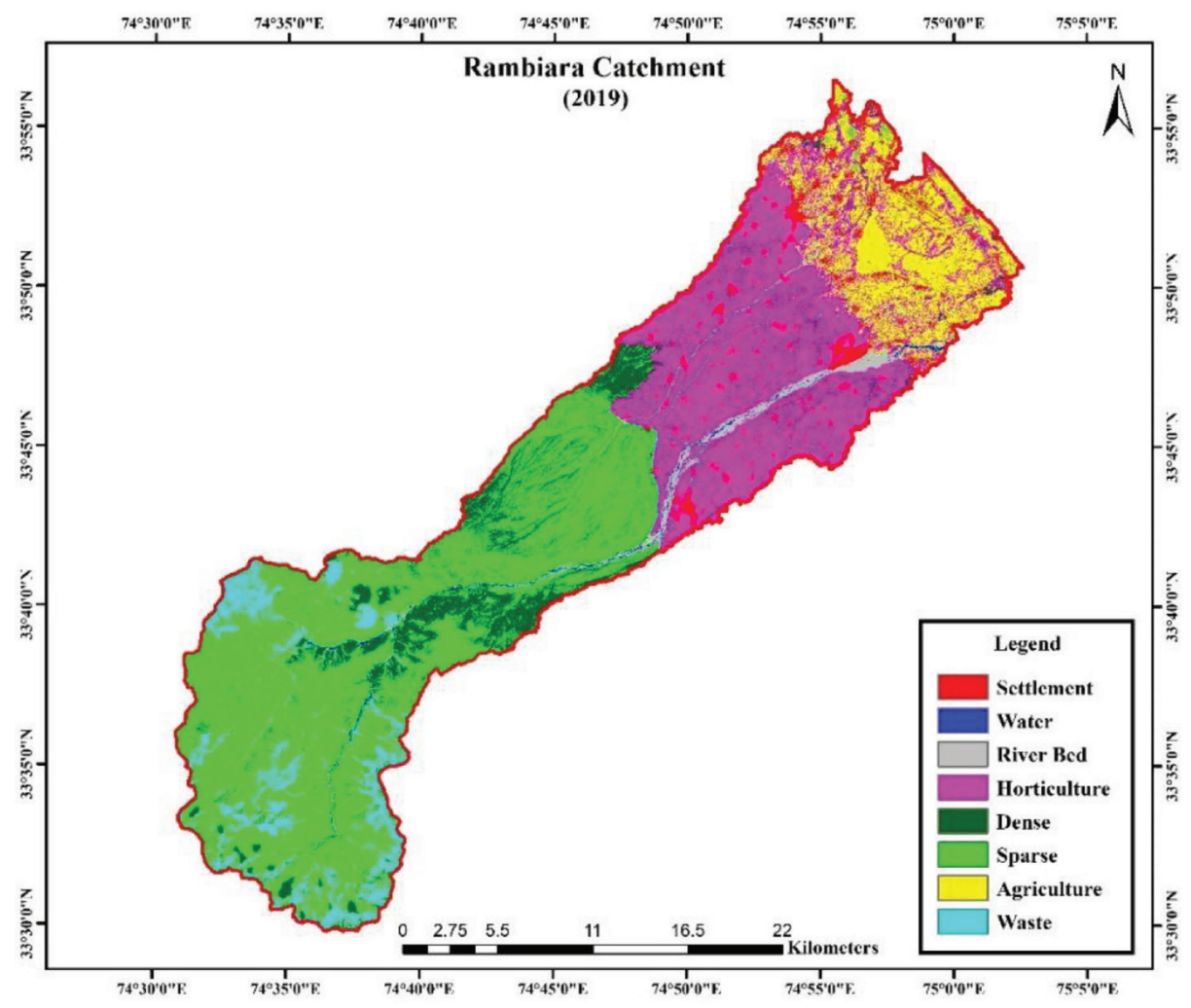

Figure 3: LULC, 2019 (Source: Prepared from the image of and Landsat 8 image by the researcher).

Prevailing Agro-climatic conditions are in favour of the development of temperate fruits. A recent couple of decades witnessed a widespread diversification from the conventional agricultural cereal crops to high yielding cash-rich crops of horticulture. Vast tracts of the agricultural land earlier occupied by rice, maize, and other crops were now found under the apple orchards. The geographic system's application in association with the spatial satellite data indicated that much of the study region area had been covered by horticulture. Table 1 revealed that horticulture occupied 110.82 percent of the other land cover classes under consideration. The absolute growth rate in terms of percentage was recorded as more than 172 percent within 20 years; the area under fruits grew from $64.18 \mathrm{~km}^{2}$ in 1999 to $175 \mathrm{~km}^{2}$ in 2019 . Analysis and processing of the images collected for the study's realization arrived with the results that in the past 
two decades from 1999 to 2019, only one land use element, i.e., horticulture, expanded its footprints above cent percent. Figure 2 presents a bird's eye view about the horticultural area's situation in 1999 where it is depicted that in the middle of the study area, horticulture is found mostly on the right side of the Rambiara river. Still, while observing Figure 3 prepared for the year 2019, a large-scale variation was displayed in favor of horticulture. Figure 3 indicated that horticulture had dominated almost the whole central region of the study area in the recent period. This scenario can also be understood through the figures 5 and 6 as there is much celerity produced because of the delineation of only horticulture covered areas of both the periods of 1999 and the year 2019. The reasons for such a massive expansion of fruit cultivation and diversification of agricultural land towards horticulture kept their origin in natural, socio-economic, and anthropogenic situations. Much of the fruit growers in the Rambiara catchment believe that horticulture produce is a cash-rich industry and has a good scope for the economic upliftment of the households involved in horticulture, Situation also turned in favor of horticulture in the recent couple of decades that agriculture has less production and yield capacity while their economic durability is also meager that changed the perception of the local farmers of the region to convert to words fruits. Also, an important reason is that there has been a reduction in the average precipitation, and crops dependent on water, particularly rice, have diminished and paved the way for expanding horticulture.

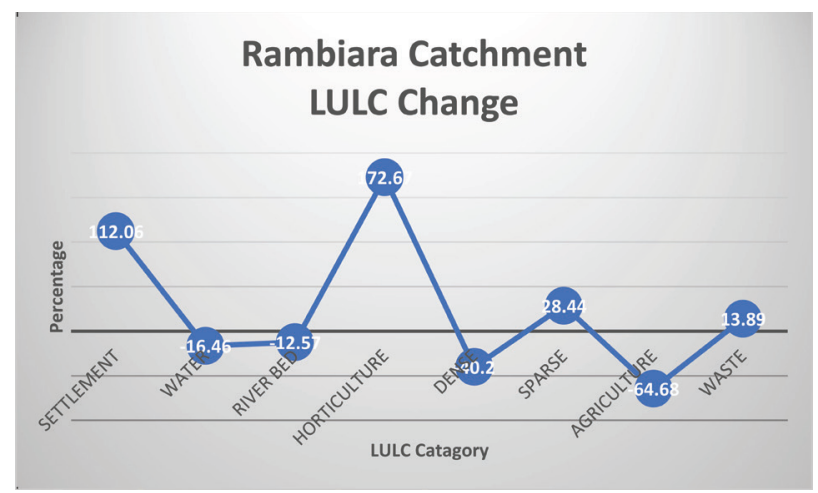

Figure 4: Percentage change in LULC Classes (Source: Compiled from the images of Landsat 7 and Landsat 8 images by the researcher).

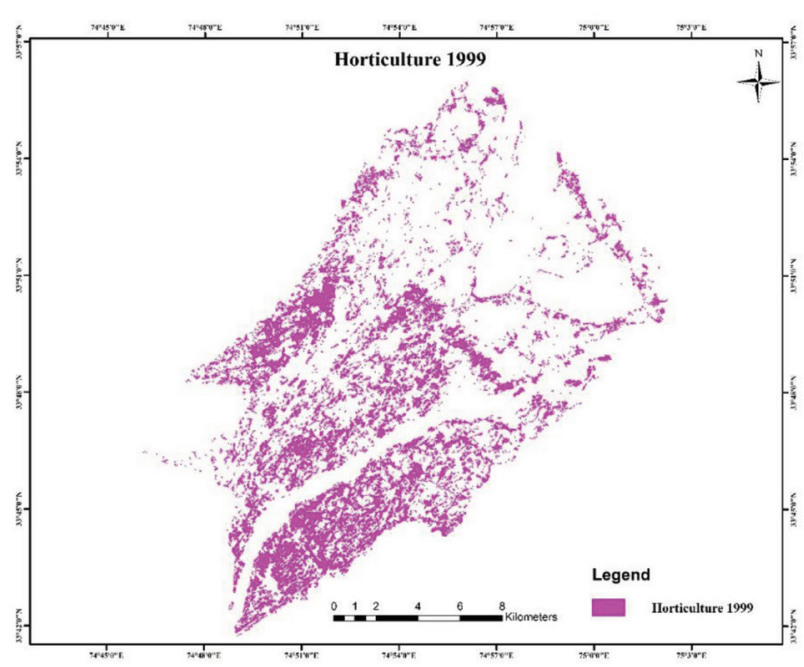

Figure 5: Area under Horticulture 1999 (Source: Prepared from the image of and Landsat 7 image by the researcher).

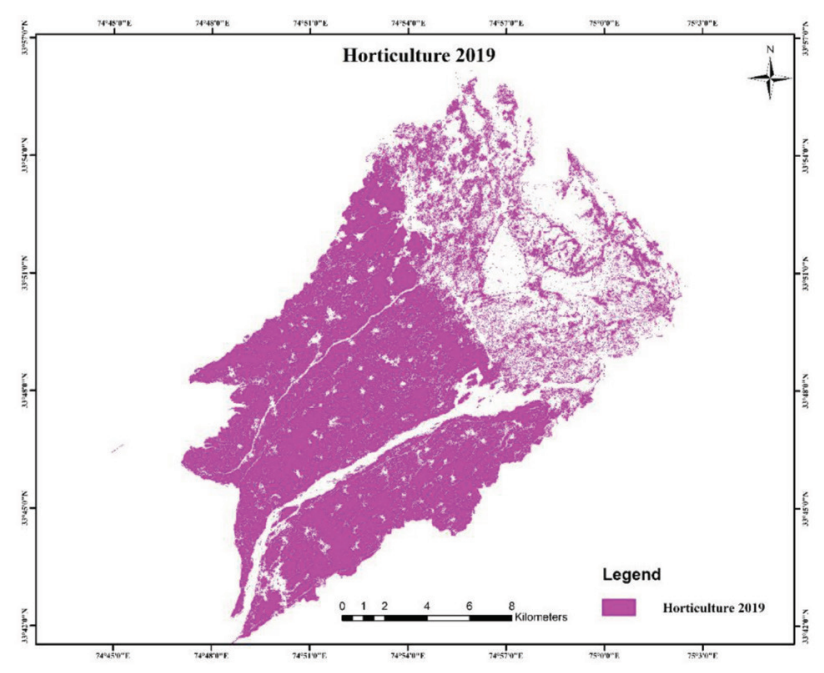

Figure 6: Area under Horticulture 2019 (Source: Prepared from the image of and Landsat 8 image by the researcher).

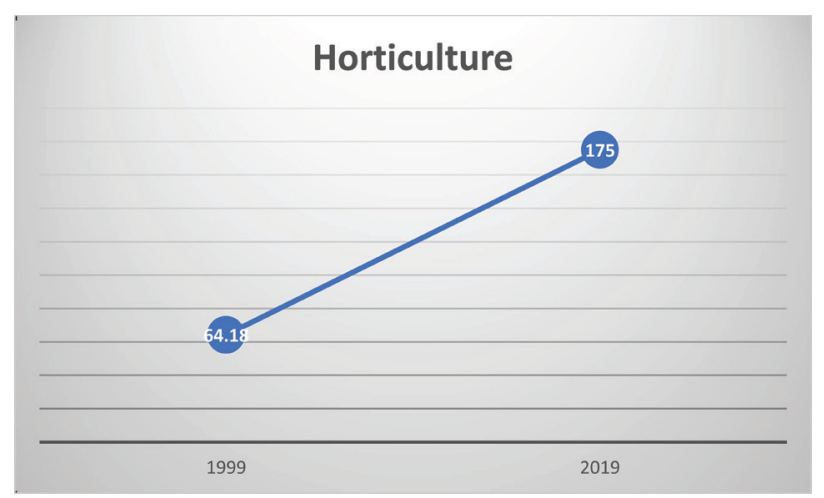

Figure 7: Growth of area under Horticulture. 


\section{Conclusion}

The land use land cover change detection is relatively common tool nowadays for the analysis and assessment of the landscape, and at the same time, it shows the magnitude of the variation over a part of the surface of the earth. In present study attempt was made to employ the same GIS and remote sensing techniques to produce the results. For the fulfilment of the objectives current study was viewed in the eight-land use land cover classes, the results obtained represented that there has been a widespread change both positive and negative observed across all the Land Use and Landcover classes in this region. It is concluded that the Land use and land cover practices in the Rambiara Watershed area have transformed pointedly in the last 20 years. The LULC shift in the catchment was palpable by the decline in the area under the dense forest category -40.20 percent Vegetation and Agriculture class - 64.68 percent, water bodies - 16.46 percent and expansion of area covered by classes of Horticulture 172.67 percent, Settlements112.06 percent, Sparce 28.44 percent and waste by 13.89 percent.Hence, well-defined management for this catchment is needed because without proper management, these valuable resource like forests and water will soon be lost and the overall socio-economic conditions of this Rambiara catchment will get disturbed.

\section{References}

Andualem, T.G., Belay, G., \& Guadie, A. (2018). Land use change detection using remote sensing technology. Journal of Earth Science and Climatic Change, 9(10), 1000496. https://doi.org/10.4172/2157-7617.1000496

Bhat, M.H. (2017). Development of horticultural sector in India-The way forward. Journal of Agroecology and Natural Resource Management, 4(4), 292-297.

Bhunia, G.S. (2019). Horticulture Development in India: Issues and Scenario of Space Technology. World Journal of Agriculture and Soil Science, 3(1), 1-5. https://doi.org/10.33552/WJASS.2019.03.000555

Butt, A., Shabbir, R., Ahmad, S.S., Aziz, N., Nawaz, M., \& Shah, M.T.A. (2015). Land cover classification and change detection analysis of Rawal watershed using remote sensing data. Journal of Biodiversity and Environmental Sciences, 6(1), 236-248.
Dar, M. (2020, July 01). Horticulture Sector, Prospects and Policy Imperatives to Support Farmers. Kashmir Images. Retrieved from https://thekashmirimages. com/2020/07/01/horticulture-sector-prospects-andpolicy-imperatives-to-support-farmers/

Darzi, M.I. (2016). Horticulture sector towards economic development of Jammu \& Kashmir. International Journal of Multidisciplinary Research and Development, 3(4), 238-240.

Deb, D., Singh, A.K., \& Kumar, S. (2018). Remote Sensing Techniques in Horticulture. In: Global HiTech Horticulture (pp.39-48). New India Publishing Agency.

Gary, C., Jones, J.W., \& Tchamitchian, M. (1998). Crop modelling in horticulture: state of the art. Scientia Horticulturae, 74(1-2), 3-20. https://doi.org/10.1016/ S0304-4238(98)00080-6

Government of India (2018). Horticulture Statistics at a Glance 2018. National Horticulture Board, Ministry of Agriculture and Farmers Welfare, Government of India.

Hassan, Z., Shabbir, R., Ahmad, S.S., Malik, A.H., Aziz, N., Butt, A., \& Erum, S. (2016). Dynamics of land use and land cover change (LULCC) using geospatial techniques: a case study of Islamabad Pakistan. SpringerPlus, 5(1), 812. https://doi.org/10.1186/s40064-016-2414-z

Horticulture Innovation Australia (2020). Horticulture and the environment. Retrieved from http:// horticulturefortomorrow.com.au/horticulture-andthe-environment/

Khursheed, V., \& Taufique, M. (2020). Spatial analysis of horticulture efficiency and fruit production concentration in Kashmir Valley. GeoJournal, 85, 1635-1643 (2020). https://doi.org/10.1007/s10708-019-10043-z

Marinelli, M.V., Scavuzzo, C.M., Giobellina, B.L., \& Scavuzzo, C.M. (2019). Geoscience and Remote Sensing On Horticulture As Support For Management and Planning. Journal of Agronomy Research, 2(2), 4354. https://doi.org/10.14302/issn.2639-3166.jar-193065

Masood, A.B., \& Pandit, A.K. (2014). Land Use/Land Cover Change Detection Studies over 25 years using Geoinformatics: A Case Study of Rambiara Catchment, Kashmir. International Journal of Environmental Sciences, 3(3), 166-170.

McKeown, A., Warland, J., \& McDonald, M.R. (2005). Long-term marketable yields of horticultural crops in southern Ontario in relation to seasonal 
climate. Canadian journal of plant science, 85(2), 431438. https://doi.org/10.4141/P03-223

Michigan State University (2020). What is Horticulture? A Modern Applied Plant Science! Retrieved form https:// www.canr.msu.edu/hrt/about-us/horticulture_is.

Nath, P., \& Gaddagimath, P.B. (Eds.) (2010). Horticulture and Livelihood Security. Scientific Publishers, Jodhpur, Rajasthan.

National Oceanic and Atmospheric Administration (NOAA) (2020). What is the difference between land cover and land use? Retrieved from https://oceanservice.noaa.gov/ facts/lclu.html\#: : :text=Land $\% 20$ cover $\% 20$ data $\% 20$ documents $\% 20$ how, $\% 2 \mathrm{C} \% 20$ conservation $\% 2 \mathrm{C} \% 20$ or\%20mixed\%20uses.

NCERT (2018). Introduction to Horticulture. Retrieved from https://ncert.nic.in/textbook/pdf/ievs101.pdf

NRSC (2020). Land Use/Land Cover. Retrieved from https://www.nrsc.gov.in/index.php/EO_LULC_ Objective?language_content_entity=en

Rao, P.P.N., Ravishankar, H.M., Raj, U., \& Nagajothi, K. (2004). Production estimation of horticultural crops using irs-1d liss-iii data. Journal of the Indian Society of Remote Sensing, 32(4), 393-398. https://doi. org/10.1007/BF03030864

Ravichandra, N.G. (2014). Horticulture and Its Role in the National Economies. In: Horticultural Nematology. Springer, New Delhi. https://doi.org/10.1007/97881-322-1841-8_1

Sarma, V.V.L.N., Krishna, G.M., Malini, B.H., \& Rao, K.N. (2001). Landuse/Landcover change detection through remote sensing and its climatic implications in the godavari delta region. Journal of the Indian Society of Remote Sensing, 29(1-2), 85-91. https://doi. org/10.1007/BF02989918

Singh, H.P., \& Malhotra, S.K. (2011, December). Horticulture for Food, Nutrition, Health Care and Livelihood Security. $4^{\text {th }}$ International Conference on Life Science Research for Rural and Agricultural Development at Central Potato Research Station, Patna.

USGS (n.d.). United states Geological Survey. Retrieved from https://earthexplorer.usgs.gov/

\section{旬 CHITKARA}

\section{Creative Space}

Chitkara University, Saraswati Kendra, SCO 160-161, Sector 9-C, Chandigarh, 160009, India

\section{Volume 8, Issue 2}

January 2021

ISSN 2321-3892

Copyright: [C 2021 Mohammad Taufique and Vajahat Khursheed] This is an Open Access article published in Creative Space (Creat. Sp.) by Chitkara University Publications. It is published with a Creative Commons Attribution-CC-BY 4.0 International License. This license permits unrestricted use, distribution, and reproduction in any medium, provided the original author and source are credited. 